P-ISSN: 2615-1723

E-ISSN: 2615-1766

April 2019
Jurnal Riset Pendidikan Dasar

02 (1), (2019) 66-73

Submitted: Februari, Accepted Maret, Published: April

\title{
Model Pembelajaran Berbasis Projek dalam Setting Lesson Study Meningkatkan Kemampuan Menulis Artikel Ilmiah Mahasiswa PGSD Undiksha
}

\author{
MG. Rini Kristiantari
}

Fakultas Ilmu Pendidikan Universitas Pendidikan Ganesha

Korespondensi. E-mail: rini_bali@yahoo.co.id

\begin{abstract}
Abstrak
Penelitian ini bertujuan memberikan bekal pemahaman dan keterampilan pada mahasiswa Jurusan Pendidikan Guru Sekolah Dasar Universitas Pendidikan Ganesha dalam menulis artikel ilmiah. Alasan yang mendasari dilakukannya kajian ini adalah adanya fakta bahwa selama ini pelaksanaan perkuliahan menulis karya ilmiah cenderung bersifat monoton, dengan teknik presentasi, diskusi, pembelajaran bersifat klasikal. Meskipun variasi metode pembelajaran baru digunakan, namun masih juga menimbulkan kejenuhan pada mahasiswa dalam belajar dikarenakan masih saja bersifat teori. Untuk itu diperlukan inovasi pembelajaran baru baik model maupun metode yang menggabungkan antara teori dan praktik pembelajaran agar mahasiswa benar-benar paham secara teori maupun praktik menulis artikel ilmiah, yakni memberikan kesempatan kepada mahasiswa belajar praktik menulis artikel di dalam maupun di luar kelas, dengan menggunakan model pembelajaran berbasis projek $(P B P)$. Kajian ini dirancang secara deskriptif kualitatif dengan setting lesson study. Subjek terteliti adalah mahasiswa semester VI PGSD FIP Undiksha di Denpasar. Data pemahaman dalam menulis artikel ilmiah serta proses kinerja mahasiswa dijaring dengan tes menulis artikel dan pengamatan langsung. Selanjutya data yang terkumpul dianalisis secara kualitatif dengan berdasar pada panduan berupa rubrik penilaian artikel ilmiah dan dipersentasekan.Hasil penelitian menunjukkan bahwa secara teori pemahaman mahasiswa terhadap teknik menulis artikel ilmiah hasil penelitian meningkat. Hal itu dibuktikan dengan skor/nilai yang diperoleh mahasiswa terteliti. Pada awal sebelum dilakukan kajian, nilai mahasiswa berada pada kategori B, C, bahkan ada yang D; setelah dilakukan kajian skor/nilai mahasiswa berada pada kategori A dan B. Hal ini berarti bahwa pembelajaran yang dilaksanakan dengan menggunakan model PBP dalam seting lesson study dapat meningkatkan pemahaman dan keterampilan mahasiswa dalam menulis artikel ilmiah.
\end{abstract}

Kata Kunci: Menulis artikel ilmiah dan pembelajaran berbasis projek

\section{Project-Based Learning Model in Lesson Study Settings Improves the Ability of Writing Undiksha Student Scientific Articles}

\begin{abstract}
This study aims to provide knowledge and skills to University Education students at Ganesha in writing scientific articles. The reason underlying this research is the fact that so far the implementation of lectures in writing scientific works has tended to be monotonous, with classical presentation, discussion and learning techniques. Although a variety of new learning methods have been used, it still causes student saturation in learning because it is still theoretical. For this reason, new learning innovations are needed, both models and methods that combine learning theory and practice so that students truly understand the theory and practice of scientific article writing, namely to provide students with the opportunity to learn the practice of writing articles inside and outside the classroom, using project-based learning model (PBP). This study was designed in a qualitative descriptive manner with lesson study settings. The subjects studied were VI semester students at Undiksha FIP in Denpasar. Data about understanding in writing scientific
\end{abstract}


articles and the process of student performance are collected by direct observation methods and article writing tests. Furthermore, the collected data is analyzed qualitatively based on the guidelines in the form of rubrics and disagreements. The results of the study indicate that in theory students' understanding of the technique of writing scientific articles results of research increases. This is evidenced by the score / value obtained by the students studied. At the beginning before the research was conducted, the student grades were in categories $B, C$, some even $D$; after this study the value of student studies is in categories $A$ and $B$. This means that learning carried out using the Project-Based Learning model in the lesson study setting can improve students' understanding and skills in writing scientific articles.

Keywords: Writing scientific articles and project-based learning

\section{PENDAHULUAN}

Menulis sebuah karya ilmiah khususnya artikel, bukan lagi sekedar hobi melainkan sudah menjadi kebutuhan dan keharusan bagi kaum intelektual, terutama mereka yang menduduki jabatan fungsional, seperti dosen, guru, peneliti, dan tak terkecuali mahasiswa, para calon guru, dan ilmuwan (Bem, 2003) Bagi mereka, menulis karya ilmiah dan artikel di media massa, jurnal penelitian, merupakan syarat mutlak untuk mendapatkan angka kredit dan untuk menaikkan jenjang jabatan fungsionalnya. Bagi mahasiswa Jurusan Pendidikan Guru Sekolah Dasar Undiksha,, menulis karya ilmiah merupakan kewajiban, sebelum mereka menyelesaikan masa studinya dan atau menempuh ujian skripsi.

Disadari bahwa menulis artikel atau karya ilmiah tidaklah semudah membuat karangan biasa (Weigle, 2007). Ide-ide atau gagasan-gagasan yang ada dalam benak kita, tidak bisa begitu saja kita tuangkan menjadi suatu tulisan artikel atau karya ilmiah. Artikel atau karya ilmiah, apalagi yang dipublikasikan melalui media cetak, ide atau gagasan itu, terlebih dulu harus disesuaikan dengan visi dan misi media cetak yang akan memuatnya, atau harus mematuhi kaidah-kaidah ilmiah dalam prosedur karya tulis ilmiah. Inilah kendala yang selama ini dihadapi oleh para dosen, peneliti, mahasiswa, dan pejabat fungsional lainnya. Ditambah lagi belum banyaknya buku panduan atau contoh tulisan yang dapat mereka jadikan rujukan.

Menulis artikel pada media massa, dan karya ilmiah pada jurnal ilmiah bagi para dosen peneliti, mahasiswa dan siapa saja yang berkecimpung di dunia ilmu pengetahuan, memang sangat penting dan dibutuhkan. Ini karena, dengan menulis artikel dan karya ilmiah, mereka akan terus berlatih untuk memecahkan permasalahan-permasalahan yang timbul baik dalam kancah keilmuan (Zanariah \& Hassan, 2011), maupun permasalahan sosial yang dihadapi pada kehidupan sosial seharihari. Dengan upaya memecahkan permasalahan itulah, daya pikir para dosen, peneliti maupun mahasiswa terus terasah, sementara pemikiran kritis mereka semakin tajam.

Sebenarnya, seiring dengan menjamurnya bisnis media cetak, kesempatan untuk menulis artikel terbuka semakin lebar. Inilah lahan subur bagi dosen, peneliti, mahasiswa, dan sebagainya, untuk berkarya memenuhi angka kredit bagi jenjang jabatan fungsionalnya. Jika karya tulisnya dimuat, selain karya tulisnya memperoleh angka kredit (credit point), juga mendapat honorium dari surat kabar atau majalah yang memuatnya. Ini merupakan penghargaan tambahan yang punya nilai tersendiri.

Sayangnya tidak semua artikel bisa menembus media massa. Selain gaya penulisan yang harus komunikatif, artikelnya pun harus sesuai dengan misi, visi dan policy media cetak tersebut. Penelitian ini mencoba untuk memberikan bekal, terutama bagi, peneliti dan mahasiswa untuk lebih mengerti dan memahami tentang tata cara penulisan artikel ilmiah dan yang lebih penting bagaimana memahami selingkung jurnal, sehingga tulisan artikelnya menjadi layak muat. Ini sangat penting mengingat kebanyakan penulis artikel gagal dimuat hanya karena tulisannya tidak sesuai dengan selingkung jurnal atau majalah yang ditujunya (Ali Saukah, 2012)

Berdasarkan pengalaman dalam memberikan kuliah serta observasi awal di kampus PGSD Undiksha UPP Denpasar, khususnya pada setiap kegiatan perkuliahan menulis karya ilmiah di semester VI, pelaksanaan perkuliahan cenderung bersifat monoton, klasikal, dengan teknik presentasi dan diskusi. Sekalipun memunculkan inovasi pada model pembelajaran yang digunakan, namun masih juga dapat menimbulkan kejenuhan pada mahasiswa dalam belajar. Untuk itu diperlukan kiat-kiat baru dari dosen dalam pembelajarannya yakni dengan mengajak 


\section{Jurnal Riset Pendidikan Dasar, 02 (1), April 2019 (66-73)}

MG. Rini Kristiantari

mahasiswa belajar langsung menulis artikel ilmiah di dalam maupun di luar kelas. Hal ini dapat memunculkan dan mengembangkan kemampuan berpikir mahasiswa guna membangun pengetahuannya sendiri melalui pengalaman langsung berinteraksi dengan lingkungan dan kelompok kerja yang sesungguhnya.

Sebagai sebuah keterampilan berbahasa, menulis merupakan kegiatan berbahasa yang paling kompleks dan pada umumnya paling akhir dikuasai secara optimal oleh mahasiswa. Hal tersebut dikarenakan dalam menulis, penulis dituntut untuk dapat menyusun dan mengorganisasikan isi tulisannya serta menuangkannya dalam formulasi ragam bahasa tulis dan konvensi penulisan lainnya (Alameddine \& Mirza, 2016) . Pembelajaran menulis karya ilmiah, merupakan dasar yang akan menentukan keterampilan menulis jenis lain bagi mahasiswa di tingkat perguruan tinggi. Sayangnya, kondisi nyata pembelajaran menulis yang teramati dan terekam dari hasil pengamatan dan pengalaman beberapa semester, khususnya keterampilan menulis artikel dan kemampuan mahasiswa dalam menulis jenis karya ilmiah untuk semua aspek/komponen belum maksimal. Hasil studi dokumen yang dilakukan pada studi awal, ratarata mahasiswa memperoleh skor/nilai cenderung kurang dan cukup baik. Jika kondisi seperti ini dibiarkan berlalu tanpa ada upaya perbaikan, dikawatirkan mahasiswa khususnya mahasiswa terteliti akan semakin mengalami kesulitan dalam mencapai tujuan akhir pendidikannya. Sesungguhnya, pembelajaran menulis artikel di perguruan tinggi hampir sebagian besar mahasiswa merupakan pengalaman pertama.

Salah satu model pembelajaran yang kiranya dapat diterapkan dalam kegiatan pembelajaran menulis karya ilmiah adalah model Project based learning (PBL) atau pembelajaran berbasis projek (PBP). PBP menurut Nurmaherawati (2014) merupakan salah satu model yang memenuhi karakteristik dasar suatu model yang kondusif bagi pengimplementasian konstruktivisme. yakni pengetahuan itu akan tumbuh dan berkembang melalui pengalaman. PBP (Project-based-learning) adalah model pembelajaran yang menggunakan projek/kegiatan sebagai proses pembelajaran untuk mencapai kompetensi sikap, pengetahuan dan keterampilan. Penekanan pembelajaran terletak pada aktivitas-aktivitas mahasiswa untuk menghasilkan produk dengan menerapkan keterampilan meneliti, menganalisis, membuat, sampai dengan mempresentasikan produk pembelajaran berdasarkan pengalaman nyata. Produk yang dimaksud adalah hasil projek dalam bentuk desain, skema, karya tulis, karya seni, karya teknologi/prakarya, dan lain-lain. Pendekatan ini memperkenankan mahasiswa untuk bekerja secara mandiri maupun berkelompok dalam mengkostruksikan produk nyata dengan berbagai metode pembelajaran yang dilakukan (Dovros \& Makrakis, 2012).

Lebih lanjut PBP disebut sebagai model pembelajaran yang menggunakan projek sebagai langkah awal dalam mengintegrasikan pengetahuan dan keterampilan baru berdasarkan pengalaman nyata. PBP dilakukan secara sistematik yang mengikutsertakan mahasiswa dalam pembelajaran sikap, pengetahuan dan keterampilan melalui investigasi dalam perancangan produk. PBP merupakan pendekatan pembelajaran yang inovatif, yang menekankan belajar kontekstual melalui kegiatan-kegiatan yang kompleks. Pelaksanaan pembelajaran berbasis projek memberikan kesempatan mahasiswa berpikir kritis dan mampu mengembangkan kreativitasnya melalui pengembangan inisiatif untuk menghasilkan produk nyata berupa barang atau jasa.

Pada PBP, mahasiswa terlibat secara aktif dalam memecahkan masalah yang ditugaskan oleh dosen dalam bentuk suatu projek. Mahasiswa aktif mengelola pembelajarannya dengan bekerja secara nyata yang menghasilkan produk riil. PBP dapat mereduksi kompetisi di dalam kelas dan mengarahkan mahasiswa lebih kolaboratif daripada bekerja sendiri-sendiri. Di samping itu PBP dapat juga dilakukan secara mandiri melalui bekerja mengkonstruk pembelajarannya melalui pengetahuan serta keterampilan baru, dan mewujudkannya dalam produk nyata.

Berdasarkan teori dan kenyataan yang telah dipaparkan, penulis sangat tertarik untuk mengadakan penelitian guna melihat keefektifan penerapan model PBP pada mahasiswa semester VI PGSD FIP Undiksha UPP Denpasar. Atas dasar alasan itulah penelitian berjudul Penerapan Model Pembelajaran Berbasis Projek / Project Based Learning dalam Seting Lesson Study untuk Meningkatkan 
Jurnal Riset Pendidikan Dasar, 02 (1), April 2019 (66-73)

MG. Rini Kristiantari

Kemampuan Menulis Artikel Ilmiah Mahasiswa Semester VI PGSD FIP Undiksha UPP Denpasar ini dilakukan.

\section{METODE PENELITIAN}

Penelitian Pembelajaran ini dirancang secara deskriptif kualitatif dalam setting lesson $s t u d y$. Ada tiga tahapan penting yang dilakukan peneliti dalam kajian ini yakni, tahap plan, do, dan see. ,

\section{Tahap Persiapan Tindakan (Plan)}

Pada tahap persiapan tindakan, langkahlangkah yang dilakukan yaitu, 1) menyusun Rancangan Pelaksanaan Pembelajaran (RPP), 2) menyusun media dan sumber pembelajaran (alat peraga, LKM, silabus, dan kurikulum) yang digunakan selama pembelajaran, menyusun instrumen penelitian berupa rubric penilaian menulis artikel ilmiah.

\section{Tahap Pelaksanaan Tindakan (do)}

Kegiatan yang dilakukan yaitu; 1) menentukan subjek terteliti, dalam kajian ini subjek terteliti diambil satu kelas mahasiswa semester VI PGSD Kelas J; 2) melaksanakan penelitian, yakni mengimplementasikan model pembelajaran berbasis proyek seting lesson study pada kelas terteliti yang berlangsung selama 8 kali pertemuan. Pertemuan pertemuan pertama dan kedua diisi dengan pemberian informasi atau penjelasan akan tugas proyek yang harus dilaksanakan, 1 kali pertemuan melakukan open kelas, dilanjutkan dengan menyelesaikan tugas proyek.

\section{Tahap observasi (see)}

Kegiatan yang dilakukan pada tahap ini peneliti mengamati proses pembelajaran dan mencatat hal hal penting yang muncul dan terjadi selama proses melaksanakan projek seperti kekurangan dan kelebihan pelaaksanaan terutama aktivitas menyangkut ketelitian, ketepatan dan antusias mahasiswa dalam proses perkuliahan.

\section{Tahap Refleksi}

Pada tahap refleksi, langkah-langkah yang dilakukan adalah menganalisis hasil tahap see dengan teman sejawat selaku kolaborator untuk selanjutnya bersama sama mencari pemecahan masalah guna sempurnanya kegiatan do yang berikut.
Subjek terteliti adalah mahasiswa semester VI Klas J PGSD FIP Undiksha UPP Denpasar berjumlah 40 orang. Data penelitian berupa kemampuan menulis artikel ilmiah dikumpulkan dengan metode tugas yakni tugas menyusun atau menulis artikel ilmiah hasil penelitian .

Menurut Sudijono (2011:67), tes adalah cara atau prosedur dalam rangka pengukuran dan penilaian di bidang pendidikan, yang berbentuk pemberian tugas atau serangkaian tugas yang berupa pertanyaan atau perintah sehingga dapat menghasilkan nilai yang melambangkan tingkah laku atau prestasi seseorang. Instrumen yang digunakan untuk mengumpulkan data kemampuan menulis artikel ilmiah adalah tes keterampilan menulis. Data yang terkumpul selanjutnya dianalisis secara deskriptif kualitatif. Data yang ada dibandingkan/dimasukkan ke dalam instrument yang digunakan berupa rubrik penilaian tes keterampilan menulis artikel, yang selanjutnya dipersentasekan berdasarkan table yang berikut (Arikunto, 2006).

Tabel 1 Kriteria Hasil Belajar Menulis Artikel

\begin{tabular}{cc}
\hline Persentase & Kreteria hasil belajar \\
\hline $85-100$ & Sangat tinggi \\
$70-84$ & Tinggi \\
$55-69$ & Sedang \\
$45-54$ & Rendah \\
$\leq 45$ & Sangat Rendah \\
\hline
\end{tabular}

\section{HASIL DAN PEMBAHASAN}

\section{Hasil}

Berdasar pada analisis data yang dilakukan pada bab sebelumnya dapat dipaparkan bahwa mahasiswa sudah memiliki pemahaman yang lebih baik tentang konsep artikel ilmiah. Artikel ilmiah yang dimaksud meliputi: (a) Bagian awal: Judul, Abstrak, dan kata kunci, (b) Bagian Inti: pendahuluan, metode, hasil, pembahasan, dan penutup, (c) bagian akhir: Penutup, dan bahasa. Pemahaman yang baik akan konsep artikel yang diperoleh mahasiswa didasarkan pada pencapaian persentase hasil proyek tentang menulis artikel ilmiah, berada pada rentangan 85-92 termasuk dalam kategori "sangat tinggi", ini berarti para responden yang adalah mahasiswa pendidikan guru sekolah dasar semester VI telah memahami tentang apa yang dimaksud artikel ilmiah. Jika 


\section{Jurnal Riset Pendidikan Dasar, 02 (1), April 2019 (66-73)}

MG. Rini Kristiantari

dikonversikan ke dalam penilaian huruf, mahasiswa yang mendapatkan nilai A mencapai $50 \%$ dan mahasiswa yang mencapai nilai $\mathrm{B}$ juga $50 \%$. Tidak ada lagi mahasiswa yang memperoleh nilai $\mathrm{C}$ apalagi nilai $\mathrm{D}$.

Hasil tersebut menunjukkan peningkatan mahasiswa dalam memperoleh nilai tugas menulis artikel. Sebelum dilaksanakan penelitian berbasis kaji tindak ini, mahasiswa yang mengikuti tes awal menulis artikel ilmiah hanya memperoleh nilai B (30\%) dan sisanya memperoleh nilai C $(62.5 \%)$ bahkan ada yang mendapatkan nilai D (7.5\%). Berikut adalah table hasil tes data awal dan akhir mahasiswa terteliti.

Tabel 1: Tabulasi Data Awal Keterampilan Menulis Mahasiswa Terteliti

\begin{tabular}{|c|c|c|c|c|c|c|c|c|c|c|c|c|c|}
\hline \multicolumn{2}{|c|}{ ASPEK YANG DINILAI } & 1 & 2 & 3 & 4 & 5 & 6 & 7 & 8 & 9 & 10 & \multirow{2}{*}{$\begin{array}{l}\text { Jmlh } \\
\text { skor }\end{array}$} & \multirow{2}{*}{ Nilai } \\
\hline No & RESPONDEN & \multicolumn{10}{|c|}{ Skor } & & \\
\hline 1 & MT01 & 4 & 3 & 5 & 3 & 4 & 3 & 3 & 4 & 3 & 3 & 35 & 70 \\
\hline 2 & MT02 & 4 & 3 & 5 & 3 & 4 & 3 & 3 & 4 & 3 & 3 & 35 & 70 \\
\hline 3 & MT03 & 4 & 3 & 5 & 3 & 4 & 3 & 3 & 4 & 3 & 3 & 35 & 70 \\
\hline 4 & MT04 & 4 & 4 & 5 & 3 & 3 & 3 & 3 & 4 & 3 & 3 & 35 & 70 \\
\hline 5 & MT05 & 3 & 3 & 5 & 3 & 4 & 3 & 3 & 4 & 3 & 3 & 34 & 68 \\
\hline 6 & MT06 & 3 & 3 & 5 & 3 & 4 & 3 & 3 & 4 & 3 & 3 & 34 & 68 \\
\hline 7 & MT07 & 3 & 2 & 5 & 2 & 4 & 3 & 2 & 4 & 3 & 3 & 31 & 62 \\
\hline 8 & MT08 & 3 & 2 & 4 & 2 & 3 & 3 & 2 & 4 & 3 & 2 & 28 & 56 \\
\hline 9 & MT08 & 3 & 4 & 4 & 2 & 3 & 3 & 3 & 4 & 3 & 3 & 32 & 64 \\
\hline \multicolumn{14}{|l|}{ Dst... } \\
\hline 40 & MT06 & 4 & 4 & 5 & 4 & 4 & 4 & 3 & 4 & 4 & 4 & 40 & 80 \\
\hline $\begin{array}{l}\text { Jumlah } \\
\% \text { Per Aspek }\end{array}$ & & $\begin{array}{l}147 \\
65.33 \\
\end{array}$ & $\begin{array}{l}126 \\
56.00 \\
\end{array}$ & $\begin{array}{l}176 \\
78.22 \\
\end{array}$ & $\begin{array}{l}118 \\
52.44 \\
\end{array}$ & $\begin{array}{l}138 \\
61.33 \\
\end{array}$ & $\begin{array}{l}123 \\
54.67 \\
\end{array}$ & $\begin{array}{l}107 \\
47.56 \\
\end{array}$ & $\begin{array}{l}158 \\
70.22 \\
\end{array}$ & $\begin{array}{l}120 \\
53.33 \\
\end{array}$ & $\begin{array}{l}114 \\
50.67 \\
\end{array}$ & & \\
\hline Skor:225x100 & & & & & & & & & & & & & \\
\hline
\end{tabular}

Tabel 2: Tabulasi Data Akhir Keterampilan Menulis Artikel Mahasiswa Terteliti

\begin{tabular}{|c|c|c|c|c|c|c|c|c|c|c|c|c|c|}
\hline \multicolumn{2}{|c|}{ ASPEK YANG DINILAI } & 1 & 2 & 3 & 4 & 5 & 6 & 7 & 8 & 9 & 10 & $\begin{array}{l}\text { Jumlah } \\
\text { Skor }\end{array}$ & Nilai \\
\hline No. & RESPONDEN & \multicolumn{10}{|c|}{ SKOR } & & \\
\hline 1 & MT01 & 4 & 4 & 5 & 4 & 5 & 4 & 4 & 4 & 5 & 4 & 43 & 86 \\
\hline 2 & MT02 & 4 & 4 & 5 & 4 & 5 & 4 & 4 & 4 & 5 & 4 & 43 & 86 \\
\hline 3 & MT03 & 4 & 5 & 5 & 4 & 4 & 4 & 4 & 4 & 5 & 4 & 43 & 86 \\
\hline 4 & MT04 & 4 & 4 & 5 & 4 & 5 & 4 & 4 & 4 & 5 & 4 & 43 & 86 \\
\hline 5 & MT05 & 4 & 4 & 5 & 4 & 5 & 4 & 5 & 4 & 5 & 4 & 44 & 88 \\
\hline 6 & MT06 & 4 & 5 & 5 & 4 & 5 & 4 & 5 & 4 & 5 & 4 & 45 & 90 \\
\hline 7 & MT07 & 4 & 4 & 5 & 4 & 4 & 4 & 3 & 4 & 5 & 4 & 41 & 82 \\
\hline 8 & MT08 & 4 & 4 & 5 & 3 & 5 & 4 & 3 & 4 & 5 & 3 & 40 & 80 \\
\hline 9 & MT08 & 4 & 5 & 5 & 4 & 5 & 4 & 4 & 4 & 4 & 3 & 42 & 84 \\
\hline \multicolumn{14}{|l|}{ Dst... } \\
\hline 40 & MT06 & 4 & 4 & 5 & 4 & 4 & 4 & 3 & 4 & 4 & 4 & 40 & 80 \\
\hline Jumlah & & 162 & 165 & 200 & 158 & 189 & 166 & 156 & 161 & 180 & 157 & & \\
\hline $\begin{array}{l}\% \text { Per } \\
\text { Aspek }\end{array}$ & & 72.00 & 73.33 & 88.89 & 70.22 & 84.00 & 73.78 & 69.33 & 71.56 & 80.00 & 69.78 & & \\
\hline
\end{tabular}


Jurnal Riset Pendidikan Dasar, 02 (1), April 2019 (66-73)

MG. Rini Kristiantari

Tabel 3: HASIL ANALISIS TERHADAP 10 ASPEK ARTIKEL

\begin{tabular}{|l|l|l|l|}
\hline No & Aspek yang Dinilai & \multicolumn{2}{|c|}{ Hasil Perbandingan } \\
\hline 1. & AWAL & Awal & Akhir \\
\hline & Perumusan judul artikel & 65.33 & 72.00 \\
\hline & Perumusan abstrak & 56.00 & 73.33 \\
\hline & Kata kunci & 78.22 & 88.89 \\
\hline 2. & INTI/ISI & & \\
\hline & Pendahuluan & 52.44 & 70.2 \\
\hline & Metode & 61.33 & 84.00 \\
\hline & Hasil & 54.67 & 73.78 \\
\hline & Pembahasan & 47.56 & 69.33 \\
\hline & Penutup & 70.22 & 71.56 \\
\hline 3. & PENUTUP & & \\
\hline & Daftar rujukan & 53.33 & 80.00 \\
\hline & Bahasa & 50.67 & 69.78 \\
\hline
\end{tabular}

Mahasiswa menyadari bahwa untuk dapat memperoleh pemahaman yang maksimal terhadap sebuah karya ilmiah berupa artikel hasil penelitian pola pembelajaran diupayakan berpindah dari yang berpusat pada dosen, menjadi berpusat pada mahasiswa. Oleh karenanya, dengan PBP yang dikemas dalam kegiaan lesson study hubungan kolaboratif antara sesama mahasiswa tercipta. Dalam proses perkuliahannya dosen juga memahami bahwa artikel ilmiah menuntut adanya pembelajaran yang interaktif antara sesama mahasiswa, juga antara mahasiswa dan dosen. Pembelajaran dilakukan melalui model PBP tidak lagi bersifat monodisiplin, melainkan multidisiplin.

\section{Pembahasan}

Seperti telah dipaparkan di bagian terdahulu bahwa tujuan utama penulisan artikel ilmiah adalah mengembangkan sikap ilmiah disamping kemampuan intelektual dan psikomotorik mahasiswa. Dalam proses pembelajarannya ketiga ranah dikembangkan secara utuh (holistik). Menulis dan menyusun sebuah karangan ilmiah bagi beberapa orang merupakan pekerjaan menyulitkan. Hal itu wajar saja terjadi, karena dalam menulis karya ilmiah ada batasan - batasan yang harus diperhatikan. Selain itu, pada karya ilmiah, ada pula tuntutan atau harapan tertentu yang harus dipenuhi oleh seorang calon penulis. Dalam menulis karya ilmiah tidak dapat menggunakan pedoman dan aturan yang berlaku untuk dirinya, tetapi pedoman dan aturan yang berlaku secara konvensional pada kelompok tertentu, (Cassell, 2008).

(Friedman, 1998) dan Djuroto, dkk (2003) mengungkapkan tujuan karya ilmiah adalah untuk menyampaikan gagasan penulis dengan caranya sendiri. Meskipun demikian karya ilmiah yang dibuat seorang penulis seharusnya tersusun dengan memperhatikan pemikiran atau pendapat orang lain melalui perujukan, itu tidak berarti penulis hanya menulis ulang pendapat penulis lain, tetapi harus juga memperlihatkan pribadi penulis bersangkutan. Sebuah artikel yang ditulis berdasarkan kajian penelitian, pada umumnya ditulis lebih ringkas dibandingkan dengan laporan penelitian itu sendiri. Artikel hanya memaparkan permasalahan, analisis dan temuan yang diperoleh penulis. Bahkan karena gaya selingkung yang berbeda-beda, staf sebuah penerbitan jurnal ilmiah dapat melakukan penyuntingan atas artikel yang diterima sehingga tulisan menjadi lebih ringkas dan layak muat. Hal ini masuk akal karena jurnal ilmiah memiliki jumlah halaman yang terbatas.

Atas hasil penelitian yang dilakukan ini, mahasiswa telah menyadari bahwa selama ini mereka memiliki kesalahan yang sama dalam mempersepsi jurnal ilmiah. Mahasiswa beranggapan bahwa kata jurnal yang sering didengar dipersepsikan sebagai sebuah artikel. Artikel yang sesungguhnya masih cukup awam bagi sebagian besar mahasiswa terteliti. Hal 


\section{Jurnal Riset Pendidikan Dasar, 02 (1), April 2019 (66-73) \\ MG. Rini Kristiantari}

tersebut dapat dimaklumi karena selama ini sangat jarang dan bahkan hampir tidak pernah dosen menugaskan pada mahasiswa untuk menulis artikel. Dominasi kegiatan mahasiswa di kelas adalah presentasi atas tugas membuat makalah yang disusun dan diskusi. Menyusun sebuah artikel ilmiah hasil penelitian pada kajian penelitian ini adalah pengalaman baru dan pertama bagi mahasiswa terteliti. Oleh karenanya meski sulit, mahasiswa melakukannya dengan penuh semangat dan tanggung jawab. Pembelajaran yang dirancang dengan PBP memungkinkan mahasiswa belajar menyusun artikel secara nyata dan bermakna. Tanpa praktik langsung menyusun artikel berdasar pada rambu-rambu yang ada, mustahil mahasiswa dapat memahami struktur artikel ilmiah hasil penelitian yang baik dan berlaku secara umum, dan dapat membuat artikel dengan hasil yang relative baik.

Seperti telah dijelaskan oleh Ali Saukah (2012) bahwa struktur atau sistematika artikel ilmiah hasil penelitian yang berlaku pada umumnya memiliki selingkung yang berikut: (1). Judul. Judul merupakan bagian penting dalam artikel hasil penelitian karena bisa menarik perhatian pembaca. Agar pembaca tertarik, judul sebaiknya menarik keingintahuan pembaca meskipun tetap memperhatikan topik utama artikel. Namun demikian, judul seyogyanya singkat, padat dan tidak terlalu panjang, maksimal 15 kata. Judul artikel yang berasal dari penelitian kualitatif mendeskripsikan konsep utama yang menjadi topik penelitian. Apabila penelitian yang dilakukan adalah kuantitatif, judul mencantumkan hubungan antar variabel yang diteliti. (2). Abstrak. Abstrak merupakan gambaran singkat artikel yang memuat aspek-aspek penting dalam penelitian. Jumlah kata dalam abstrak beragam tapi dalam abstrak yang berbahasa Inggris jumlah kata maksimal yang disarankan adalah 300 kata. Abstrak terdiri dari 3 bagian, meliputi: masalah atau tujuan penelitian, prosedur penelitian dan ringkasan hasil penelitian. Pada bagian bawah abstrak mencantumkan kata kunci sebanyak 3 - 5 kata. (3). Pendahuluan. Pendahuluan merupakan bagian yang mengambarkan skenario dari susunan artikel dengan panjang kurang lebih 10 persen dari artikel secara keseluruhan. Sebagai bagian yang menggambarkan struktur artikel, pendahuluan harus mudah dimengerti dan menarik sehingga keingintahuan pembaca menjadi lebih besar untuk membaca bagian utama dari artikel. (4). Bagian utama artikel adalah inti dari artikel karena memuat analisis dan temuan dari penelitian. Pada bagian ini artikel terbagi menjadi beberapa sub judul sesuai dengan hasil penelitian, analisis dan temuan teoritis penelitian. Pada penelitian kuantitatif, diperlukan subjudul tersendiri untuk menjelaskan metode penelitian dan analisis karena dalam penelitian kuantitatif instrument penelitian sangat penting sebagai alat untuk melakukan analisis. Bahkan proses penyusunan instrument untuk melakukan analisis harus dijelaskan dengan baik sehingga replikasi atas metode penelitian dapat dilakukan oleh orang lain yang ingin melakukan pengujian atas instrument tersebut.

Hal tersebut berbeda dengan jenis artikel dari hasil penelitian kualitatif yang lebih fleksibel dalam penyusunan bagian utama. Bahkan pedekatan konseptual yang menjadi perdebatan awal penelitian dapat menjadi subjudul tersendiri. Di samping itu, hasil penelitian bisa langsung dianalisis sehingga pembahasan lebih mendalam. Meskipun hasil penelitian langsung dibahas, hal ini tidak menjamin laporan penelitian menjadi tipis karena analisis konseptual dalam penelitian kualitatif menuntut analisis yang mendalam.

Pembahasan (analisis) penelitian pada umumnya dan semestinya merupakan bagian terpanjang dalam artikel. Hal ini berlaku pada laporan penelitian maupun artikel hasil penelitian baik kuantitatif maupun kualitatif. Mengapa demikian? Pada bagian ini memaparkan hasil diskusi tentang konsep, fakta-fakta dan temuan yang menjadi sintesa penulis. Dalam diskusi, dibahas keterkaitan antara kajian teori dan hasil penelitian secara terus-menerus hingga melahirkan temuan faktual maupun teoritis yang menjadi jawaban atas pertanyaan penelitian. Di samping itu, peneliti juga melakukan interpretasi secara mendalam terhadap berbagai fakta dan informasi dan diintegrasi menjadi temuan penting dari penelitian. Dalam proses ini penulis harus secara teliti membaca hasil penelitian, mendiskusikannya dengan pihakpihak yang relevan maupun menuliskan dengan cara yang menarik. (5). Simpulan. Bagian ini berisi jawaban atas pertanyaan penelitian yang menjadi tujuan penulisan artikel. Hal ini harus benar-benar dipahami terutama pada saat akan menulis artikel hasil 
penelitian. Berdasarkan simpulan yang diperoleh, pada sebuah artikel dapat diajukan saran pada pembaca untuk melakukan perbaikan atas permasalahan yang muncul. Bahkan artikel dapat melakukan proyeksi atas topik artikel sehingga terbuka peluang untuk melakukan penelitian lanjutan. Peluang untuk melakukan penelitian lanjutan sangat penting sebagai upaya untuk mengetahui lebih mendalam topik yang menjadi kajian dalam artikel. (6). Daftar Pustaka. Daftar pustaka merupakan bagian yang tidak terpisahkan dalam artikel ilmiah karena menjadi bukti rujukan atas berbagai sumber yang digunakan dalam artikel. Dengan demikian posisinya menjadi sangat penting.

\section{SIMPULAN}

Berdasarkan hasil analisis data penelitian yang dilakukan, dapat ditarik simpulan yang berikut: (1) Secara teoretis pemahaman dan kemampuan menulis artikel ilmiah mahasiswa terteliti cenderung meningkat meski belum sempurna, (2) Terbatasnya media jurnal yang ada saat penelitian ini dilaksanakan menjadikan artikel yang berhasil ditulis mahasiswa belum dapat dipublikasikan; (3) Pembelajaran berbasis projek dalam seting lesson study dapat meningkatkan kemampuan mahasiswa semester VI PGSD Undiksha UPP Denpasar dalam menulis artikel ilmiah berupa hasil penelitian.

Mengacu pada simpulan yang dipaparkan yakni pentingnya pengetahuan serta pemahaman mahasiswa terhadap cara menulis artikel yang baik dan layak muat pada sebuah jurnal, diharapkan ada pelatihan-pelatihan yang dilakukan kepada mahasiswa nonterteliti terkait dengan upaya meningkatkan pemahaman dan keterampilannya dalam menulis artikel ilmiah hasil penelitian.

\section{DAFTAR PUSTAKA}

Alameddine, M. M., \& Mirza, H. S. (2016). Teaching Academic Writing for Advanced Level Grade 10 English. Procedia - Social and Behavioral Sciences, pp. 209-216. The Author(s). https://doi.org/10.1016/j.sbspro.2016.10. 048.

Ali, S. (2012). Langkah-Langkah Penulisan Artikel Ilmiah, http: //www. docstoc.
com/docs/104643910/LANGKAHLANGKAH-PENULISAN-ARTIKELILMIAH, diunduh 15 Mei 2015.

Arikunto, S. (2012). Dasar-Dasar Evaluasi Pendidikan. Jakarta: PT Bumi Aksara.

Bem, D. J. (2003). Writing the Empirical Journal Article. American Psychological Association, 171-201.https://doi.org/10.1126/science.120.3128.981-a

Cassell, C. (2008). Template Analysis. In The Sage Dictionary of Qualitative Management Research (pp. 63-65). https://doi.org/10.4135/978085702010

Djuroto, T., \& Bambang Suprijadi. (2003). Menulis Artikel \& Karya Ilmiah. Bandung: Remaja Rosda Karya.

Dovros, N., \& Makrakis, V. (2012). Transforming the classroom into a reflective community: A blended learning instructional aproach. Journal of Teacher Education for Sustainability, 14(2), 73-88. https://doi.org/10.2478 /v10099-0120010-z $\backslash$

Friedman, K. (1998). Writing a better scientific article. Reviews of Modern Physics Style Guide, $\quad 1-14$. https://doi.org/10.1086/532756

Nurmaherawati. (2014) Pendekatan Pembelajaran Berbasis Proyek. Diunduh dari https://nurmaherawatifaizal.wordpress.c om/2014/04/29/pendekatan

pembelajaran-berbasis-proyek/, diakses tgl 31 Maret 2015

Sudijono, A. (2011). Pengantar Evaluasi Pendidikan. Jakarta: PT Rajagrafindo Persada.

Weigle, S. C. (2007). Teaching writing teachers about assessment. Journal of Second Language Writing, 16(3), 194-209.

Zanariah, C. H. E., \& Hassan, C. H. E. (2011). Pelaksanaan pengajaran dan pembelajaran kemahiran menulis di sekolah rendah. Malay Language Education Journal (MyLEJ), 1(1), 67-87. 